\title{
Basic principles of stable isotope analysis in humanitarian forensic science.
}

CHESSON, L. A., MEIER-AUgENSTEIN, W., BERG, G. E., BATAILLE, C. P., BARTELINK, E. J., and RICHARDS, M. P. 


\section{Basic Principles of Stable Isotope Analysis in Humanitarian Forensic Science}

Lesley A. Chesson*1 and Wolfram Meier-Augenstein*2

Gregory E. Berg ${ }^{3}$, Clement P. Bataille ${ }^{4}$, Eric J. Bartelink ${ }^{5}$, and Michael P. Richards ${ }^{6}$

${ }^{1}$ PAE, Contractor at the Defense POWMIA Accounting Agency (DPAA) Laboratory; 590 Moffet Street, Building 4077, Joint Base Pearl Harbor-Hickam, HI 96853, USA

${ }^{2}$ Professor, Robert Gordon University; School of Pharmacy and Life Sciences, The Ian Wood Building, Garthdee Road, Aberdeen, AB10 7GJ, UK

${ }^{3}$ Laboratory Manager, Scientific Analysis, DPAA Laboratory; 590 Moffet Street, Building 4077, Joint Base Pearl Harbor-Hickam, HI 96853, USA

${ }^{4}$ Assistant Professor, University of Ottawa; Department of Earth and Environmental Sciences, FSS Hall, 120 University, Room 15025, Ottawa, ON K1N 6N5, Canada

${ }^{5}$ Professor, California State University, Chico; 400 West First Street, Department of Anthropology, Chico, CA 95929-0400, USA

${ }^{6}$ Professor, Simon Fraser University; Department of Archaeology, Simon Fraser University, 8888 University Drive, Burnaby, BC V5A 1S6, Canada

*Co-lead authors 


\section{Introduction}

While the identity of a victim of a localized disaster - such as a train or bus crash - may be established quickly through personal effects, fingerprints, dental records, and a comparison of decedent DNA to family reference specimen DNA, a different scenario presents itself in mass disasters, such as the Asian Tsunami of 2004. In the aftermath of the tsunami visual appearance was initially used to assign "foreign" or "indigenous" classifications to the remains of thousands of victims. However, this visual identification approach was undermined by the speed with which bodies deteriorated under the hot and humid conditions. Time was spent populating antemortem DNA databases for different nationalities, which led to problems when creating a postmortem DNA database because recovery of viable DNA was compromised due to rapid decomposition. As a consequence, only $1.3 \%$ of victims were identified by DNA; in contrast, $61 \%$ were identified based on dental examination [1], although this process took several months and a significant number of deceased from the 2004 Asian Tsunami still remain to be identified.

Although not challenged by the numbers typically encountered in mass fatalities, investigations of serious crime against a person can be hampered when a victim's body is badly decomposed, or when mutilation (usually postmortem) has taken place, making it difficult to establish identity. Mutilation typically involves destruction of facial features including dentition or complete decapitation and can extend to the removal of hands and feet. Decapitation rules out craniofacial comparisons and approximations [2,3] as well as dental examination while fingerprints - if available and recoverable - may not lead to an immediate identification if the victim's fingerprints have never been taken and entered into a database. Without other distinguishing features such as jewelry, clothing, or body art [4], identification of mutilated murder victims becomes nigh impossible using traditional investigative techniques.

Common to both situations is the need for screening tools in support of human identification. Isotope ratios of hydrogen $(\mathrm{H})$, carbon $(\mathrm{C})$, nitrogen $(\mathrm{N})$, oxygen $(\mathrm{O})$, sulfur $(\mathrm{S})$, strontium $(\mathrm{Sr})$, and lead $(\mathrm{Pb})$ act as "nature's recorders" [5]. Chemical recording devices such as hair, nail, bone, or teeth provide an information repository as to where a person lived and the types of foods consumed. Differences in tissue formation or remodeling rates result in time-averaged records going back months (hair, nail) or years (bone, tooth enamel). Once the isotope record has been measured, it can be translated into information about geographic life trajectories and dietary patterns [6]. This information can aid in the process of identification, typically by eliminating scenarios but potentially by revealing life history details that could be included in a public appeal for information. It must be stressed, however, that the isotopic profiles recorded in human tissues cannot directly identify a person outright. We note that while identification may rely in part on isotopic data, investigation of unidentified human remains will likely also include examination of other physical evidence and genetic analyses.

Here we provide some background and applications of stable isotope analysis in the context of humanitarian forensic science to illustrate the contribution isotopic profiling can make to an investigation of an unidentified decedent. We also describe a few of the isotopic tools and data resources currently available to forensic investigators. Building many of these tools required a massive undertaking over several years and future revisions will require skilled scientists, sufficient funding, and political will in equal measure. 


\section{Background on Isotopes}

Almost all natural chemical elements occur in more than one isotopic form with the vast majority being stable isotopes. Stable isotopes do not decay, unlike radioisotopes (radionuclides). Compartmental isotope abundances are not fixed but in a continuous state of flux. For example, the natural abundances on Earth for carbon-12 $\left({ }^{12} \mathrm{C}\right)$ and the one neutron heavier stable isotope carbon-13 $\left({ }^{13} \mathrm{C}\right)$ are typically given as 98.9 and 1.1 atom \%, respectively. However, when comparing ${ }^{13} \mathrm{C}$ abundances of sugar from sugar beet $\left(\mathrm{C}_{3}\right.$ photosynthesis $)$ and sugar cane $\left(\mathrm{C}_{4}\right.$ photosynthesis), we typically find they are 1.0827 and 1.0986 atom \%, respectively, even though in every other respect the sugar made by these two plants is chemically identical.

Since expressing the difference as atom $\%$ would mean dealing with very small numbers (the aforementioned difference is 0.0159 atom $\%$ ), the $\delta$-notation was introduced that linked sample isotopic composition to the internationally agreed isotopic composition of a standard zero-point. The $\delta$ value of the heavier isotope $h$ of a chemical element $\mathrm{E}$ for a given sample reported versus a given standard is defined by the below equation where $\mathrm{R}_{\text {sample }}$ is the ratio of the heavier isotope over the lighter (e.g., ${ }^{2} \mathrm{H} /{ }^{1} \mathrm{H}$ or ${ }^{13} \mathrm{C} /{ }^{12} \mathrm{C}$ ) for the sample and $\mathrm{R}_{\text {standard }}$ is the ratio for the zero-point. For $\delta^{2} \mathrm{H}$ values, that zero-point is Vienna Standard Mean Ocean Water (VSMOW); for $\delta^{13} \mathrm{C}$ values, it is defined by Vienna Pee Dee Belemnite (VPDB) [7].

$\delta^{h} \mathrm{E}_{\text {sample/standard }}=\delta^{h} \mathrm{E}_{\text {standard }}=\left(\mathrm{R}_{\text {sample }} / \mathrm{R}_{\text {standard }}\right)-1$

Eqn. 1

For carbon and the example of the two sugars, the corresponding $\mathrm{R}_{\text {sample }}$ for beet sugar and for cane sugar would be 0.0108894 and 0.0110510 , respectively. With $\mathrm{R}_{\text {standard }}$ for VPDB equal to 0.0111796 [7], the corresponding $\delta^{13} C_{V P D B}$ values are -0.02596 and -0.01150 , respectively, with the minus signs denoting a ${ }^{13} \mathrm{C}$ abundance in the samples less than that of the standard VPDB (which by virtue of Eqn. 1 has a $\delta$ value of 0 ). Since $\delta$ values derived from Eqn. 1 are numerically very small, for reasons of convenience they are typically expressed in parts per thousand (\%o); e.g. $-0.02596 \times 10^{-3}=-25.96 \%$ and $-0.01150 \times 10^{-3}=-11.50 \%$. It is important to note, \%o is neither a unit nor a unit modifier in the SI (Système International, or International System) but is purely a mathematical convention for expressing small numbers.

The $\delta$ notation as defined by Eqn. 1 has been adopted for reporting stable isotope ratios of nonmetal elements (e.g., H, C, N, O, and S), although the corresponding standard zero-points and their agreed $\mathrm{R}_{\text {standard }}$ differ. As mentioned previously, relative isotopic abundance values of ${ }^{2} \mathrm{H}$ and ${ }^{13} \mathrm{C}$ are anchored by VSMOW and VPDB, respectively. Oxygen isotope abundance values $\left(\delta^{18} \mathrm{O}\right.$ values) of carbonate minerals are traditionally anchored by VPDB. However, in all other matrices - be it water, inorganic, or organic compounds- $\delta^{18} \mathrm{O}$ values are anchored by VSMOW. Nitrogen isotope abundance values $\left(\delta^{15} \mathrm{~N}\right.$ values) are reported relative to atmosphere (Air) while $\delta^{34} \mathrm{~S}$ values are reported relative to Vienna Canyon Diablo Troilite (VCDT).

While light element non-metal C, H, N, O and S stable isotope systems are the most commonly used for isotopic profiling of human remains, heavy element metal isotope systems can provide useful information too. In particular, metal isotope systems that contain a radiogenic stable isotope (a product of the decay of a long-lived radionuclide), such as $\mathrm{Sr}$ or $\mathrm{Pb}$, are increasingly used in archaeology and forensics [8-10]. The application of these tracers are not dependent on isotopic fractionation because any isotopic fractionation is corrected for during analysis [11]. As 
such, stable isotope ratios of metal systems are typically reported as $\mathrm{R}_{\text {sample, }}$ with no conversion to $\delta$ notation - for example, ${ }^{87} \mathrm{Sr} /{ }^{86} \mathrm{Sr}$ or ${ }^{207} \mathrm{~Pb} /{ }^{204} \mathrm{~Pb}$. Variations in $\mathrm{Sr}$ or $\mathrm{Pb}$ isotope ratios are controlled by changes in the compartmental abundance of the radiogenic isotope, which increases through time due to the radiogenic decay of the parent radionuclide [11]. $\mathrm{Sr}$ and $\mathrm{Pb}$ isotope ratios of geological materials do not vary at human timescales because the parent radionuclides have very long half-lives. However, over millions of years, radiogenic isotopes can accumulate at different rates in rock reservoirs of different age and geology, leading to variations in $\mathrm{Sr}$ and $\mathrm{Pb}$ isotope ratios in the environment; these spatial isotopic variations are then propagated/mixed in water and ecosystems providing a baseline for provenance applications $[9,12]$.

\section{Isotopes in Human Tissue}

Paraphrasing the adage "you are what you eat," isotopically you are what you eat and drink give or take a few \%o for the non-metal elements. The isotopic abundances of $\mathrm{H}, \mathrm{C}, \mathrm{N}, \mathrm{O}, \mathrm{S}, \mathrm{Sr}$, and $\mathrm{Pb}$ in human tissues reflect the isotopic make-up of food consumed and water consumed or used during bathing and thus reflect a person's life history including geographic travelmovements and dietary choices [13-24]. In other words, geolocation and diet influence the isotopic composition of tissues such as hair, nail, bone, and teeth, and can be used to aid human identification.

Isotopic profiles of human tissues can provide life history or life trajectory information about an unidentified decedent, at longer-term or more recent timescales - or both-depending on the tissues available for analysis. Approximate time periods represented by the body's chemical recording devices are presented in Table 1. In contrast to the aforementioned traditional means of identification (e.g., DNA, fingerprint, or dental records), isotopic profiling does not necessarily rely on an individual-specific database. By comparing the isotopic profile of one tissue with that of another or to patterns of isotopic variation observed at the population level, it may be possible to provide information useful for identification.

The body's major source of hydrogen is water $\left(\mathrm{H}_{2} \mathrm{O}\right)$, be it from water directly consumed through liquid intake; water indirectly consumed in foods such as fruits and vegetables; water used to prepare meals and beverages; or hydrogen chemically bound in food. Although water consumed directly as liquid intake could come from a bottle or the tap, bottled water is ultimately derived from precipitation and highly correlated with local tap water [25]. Necessary resources for inferring geographic life histories include global databases of water ${ }^{\text {ab }}$, interpolated isotope landscapes or isoscapes (Figure 1) [26], and spatial or functional models for the distribution of $\mathrm{H}$ and $\mathrm{O}$ isotopes in precipitation and drinking water [27-29] and how these correlate with the corresponding isotopic compositions of human tissues [26,30-33].

The basic principle behind establishing dietary lifestyle using isotopic profiles is the fact that the body's only source of C, N, and S is a person's staple diet. This can result in significant differences in the carbon isotopic composition of tissues of people living in different world regions - for example, Europe and Asia versus North America-due to the different levels of $\mathrm{C}_{3}$ plant derived carbon (e.g., sugar beet, rice, or wheat with a relatively low ${ }^{13} \mathrm{C}$ abundance) versus

\footnotetext{
${ }^{a}$ The Global Network of Isotopes in Precipitation: http://www-naweb.iaea.org/napc/ih/IHS_resources_gnip.html

${ }^{b}$ The Waterisotopes Database: Waterisotopes.org
} 
$\mathrm{C}_{4}$ plant derived carbon (e.g., sugar cane or corn with a relatively high ${ }^{13} \mathrm{C}$ abundance) in their respective diets [34,35]. In North America, there is a pervading influence of $\mathrm{C}_{4}$ carbon derived from sugar cane, but primarily corn; corn is used as animal feedstock [36,37] and corn syrup even serves as a cheap source of sweetener in processed foods, including beverages [38].

The nitrogen isotopic composition of body tissues can be used as an indicator of a person's consumption of animal protein - i.e., carnivore versus omnivore versus vegan. In general, due to trophic level shift, $\delta^{15} \mathrm{~N}$ values increase by approximately $3.4 \%$ when moving up from one trophic level in a food web to another $[39,40]$. However, factors such as nutritional stress, health status, or pregnancy can also influence an individual's overall $\mathrm{N}$ balance and thus isotopic profile $[41,42]$. Furthermore, results from a controlled diet study suggest it may take more than 4 weeks before $\delta^{15} \mathrm{~N}$ values of tissues such as hair, plasma, or urine are changed by variations in the level and source of daily protein intake [43].

The sulfur isotopic compositions of an individual's tissues are also related to diet, and primarily indicate from where dietary protein came [22]. Sulfur in humans is present in two amino acids, cysteine and methionine, and there is very little isotopic fractionation when these amino acids are incorporated from diet into body tissues, such as bone collagen or hair keratin [15]. Sulfur in soil, the source of sulfur for most plants and animals, comes mainly from underlying Scontaining bedrock with a contribution from rainfall (and sea-spray) S [39]. Oceans have a relatively similar $\delta^{34} \mathrm{~S}$ value, freshwater systems have a wide range of $\delta^{34} \mathrm{~S}$ values worldwide, and inland locations have predictable $\delta^{34} \mathrm{~S}$ values based on bedrock $\delta^{34} \mathrm{~S}$ values. As a consequence, the measured $\delta^{34} \mathrm{~S}$ values of plants and animals in a region are distinct to that geographic location. It's thus possible to measure sulfur isotope ratios of human tissues to determine the geographical source of that $\mathrm{S}$ (consumed as dietary protein) as a tool for human provenancing. It is useful in distinguishing between inland and coastal locations [44-46], and variations in diet and geography can result in significant differences in the sulfur isotopic profiles of tissues from people living in Europe and North America [35]. The use of sulfur isotope analysis in this way is analogous to $\mathrm{Sr}$ and $\mathrm{Pb}$ (see below); however, the advantage of including sulfur isotope ratio measurements is that $\mathrm{S}$ is present in shorter-term memory tissues such as hair, whereas $\mathrm{Sr}$ and $\mathrm{Pb}$ are often measured in teeth, which form at earlier periods of life.

The $\mathrm{Sr}$ and $\mathrm{Pb}$ isotope ratios of human tissues have strong potential to complement and refine geographic life history information derived from non-metal isotope systems [47-49]. In contrast to $\mathrm{H}$ and $\mathrm{O}$, which are sourced from the atmosphere (via the hydrological cycle) and isotopically fractionate following large-scale climate processes, $\mathrm{Sr}$ and $\mathrm{Pb}$ in soils, waters, plants, and animals are sourced primarily from rocks $[10,12,50-53]$. As such, spatial patterns of $\mathrm{Sr}$ and $\mathrm{Pb}$ isotopic variation differ drastically from those of $\mathrm{H}$ and $\mathrm{O}$ and relate to the age and lithology of geological units. These geology-derived isotopic patterns are propagated and/or mixed in water and ecosystems $[9,12,54]$. However, in the case of $\mathrm{Pb}$ isotopes, industrial activities have added considerable anthropogenic $\mathrm{Pb}$ to the environment, which often dwarfs the natural $\mathrm{Pb}$ isotopic variations [55]; anthropogenic sources of $\mathrm{Pb}$, particularly aerosols, are the primary control of $\mathrm{Pb}$ isotopic variations in the present day. The spatiotemporal $\mathrm{Sr}$ and $\mathrm{Pb}$ isotopic variations from natural and anthropogenic sources are ultimately transmitted to human tissues through food/water ingestion or surface exposure. 
When considering the isotope record contained within, human tissues can be categorized in one of two ways: (1) tissues with a longer-term "memory," such as bone and teeth; and (2) tissues with a shorter-term "memory," such as hair and nail (see Table 1). The biomineral and proteinaceous fractions of bone and teeth reflect geography and diet over years by recording isotopes present in drinking water and food [48,56-58]. For the isotopic analysis of $\mathrm{Sr}$ or $\mathrm{Pb}$ in bone or tooth enamel, tissues are typically analyzed as bulk or "whole" material [48,59-61]. Hair and nail can provide a record of both geographic history and diet ranging from fourteen days up to 20 months or more, depending on the length of hair or nail available for analysis $[14,16,17,24,62-65]$.

\section{Longer-term "Memory" Tissues: Bone and Teeth}

Bone and teeth are often the longest surviving human tissues postmortem and, if conditions are favorable, can remain pristine for hundreds, even thousands of years [66]. While a tooth, in particular tooth enamel, once fully formed does not remodel and thus provides information about a person's early childhood and adolescence, bone does remodel, or turnover, though at rates ranging from $4 \%$ to $20 \%$ per year (see below). These characteristics make bone and teeth an excellent source of information in applications of isotopic profiling [6,67-69]. It also makes them an excellent resource for research in the fields of anthropology and bioarcheology and we note that current forensic applications of isotope analysis rely heavily on work carried out in an archaeological context [57,70-72]. As such, any interpretation of isotope data from the tissues of present-day people has to account for the uncertainty arising from the lack or limited extent of corresponding databases and knowledge derived from them.

\section{Oxygen Isotopic Composition of Bioapatite}

Of particular interest is the relationship between the oxygen isotopic composition of bioapatite (a group of minerals present in bone or tooth enamel) and water, since this can provide information on past geographic life trajectory. Longinelli published some of the first oxygen stable isotope analyses of human bone and teeth in 1984 [57]. More recently, a comprehensive review of studies correlating $\delta^{18} \mathrm{O}$ values of human bioapatite with $\delta^{18} \mathrm{O}$ values of drinking water has proposed a revised, unified correlation equation [58].

Water is the predominant precursor pool of oxygen found in the phosphate and carbonate components of bioapatite [56-58,73]. Compared to the inorganic mineral calcium hydroxyapatite $\mathrm{Ca}_{10}\left(\mathrm{PO}_{4}\right)_{6}(\mathrm{OH})_{2},[74-76]$, carbonate ions replace some of the hydroxyl ions and, to a lesser degree, some of the phosphate ions in bioapatite thus changing its crystal structure [77]. Since water consumed by a person contributes to the oxygen precursor pool for the formation of the bioapatite constituents $\left[\mathrm{PO}_{4}{ }^{3-}\right]$ and $\left[\mathrm{CO}_{3}{ }^{2-}\right], \delta^{18} \mathrm{O}$ values of bioapatite are strongly correlated $\left(\mathrm{R}^{2}\right.$ $=0.76)$ to $\delta^{18} \mathrm{O}$ values of water [58].

$\delta^{18} \mathrm{O}_{\text {water/VSMOW }}=1.54( \pm 0.09) \times \delta^{18} \mathrm{O}_{\text {phosphate/VSMOW }}-33.72( \pm 1.51)$

Considering the isotopic composition of drinking water reflects that of meteoric water (precipitation), $\delta^{18} \mathrm{O}$ values of water calculated from $\delta^{18} \mathrm{O}$ values of bioapatite can be used as an indicator of - or, conversely, exclusion criterion for-geographic provenance. Since both phosphate and carbonate ions in bioapatite are ultimately closely linked to the same precursor water pool, in the absence of diagenesis of the biomineral fraction of bone or tooth enamel, $\delta^{18} \mathrm{O}$ 
values for carbonate and phosphate are also strongly correlated $\left(\mathrm{R}^{2}=0.98\right)$. This correlation is given by the equation proposed by Iacumin et al. [78].

$\delta^{18} \mathrm{O}_{\text {phosphate/VSMOW }}=0.98 \times \delta^{18} \mathrm{O}_{\text {carbonate/VSMOW }}-8.5$

Eqn. 3

Most early work on bioapatite focused on the analysis of the phosphate component, but the sample preparation process is difficult and time consuming as phosphate must be precipitated as silver phosphate from fairly large samples sizes using the acute poison hydrogen fluoride to demineralize samples prior to precipitation. Oxygen isotope analysis of the carbonate component of bioapatite offers a valid alternative approach to gain information on geographic provenance, provided that diagenesis has not significantly affected the bioapatite. After a simple sample preparation process to isolate bioapatite from powdered bone using hydrogen peroxide or sodium hypochlorite, the powder is soaked in a weak solution of acetic acid, and then the carbonate component is acid digested at a constant temperature $[79,80]$ and the evolved $\mathrm{CO}_{2}$ analyzed for its ${ }^{18} \mathrm{O}$ isotopic composition.

It is important to note that the temperature at which carbonate is acid digested will affect the fractionation of ${ }^{18} \mathrm{O}$ from $\left[\mathrm{CO}_{3}{ }^{2-}\right]$ into $\mathrm{CO}_{2}$ and $\mathrm{H}_{2} \mathrm{O}$ and researchers have shown that the temperature-dependent acid fractionation factors $(\alpha)$ for "modern" enamel, "archaeological" enamel, and pure carbonate minerals follow different temperature relationships. This effect can be corrected provided the temperature of acidification is known and "raw" $\delta{ }^{18} \mathrm{O}$ data are available [81]. Because the apparent acid fractionation factor for all carbonate-containing materials is assumed to be the same at $25^{\circ} \mathrm{C}(\alpha=1.01025)$, as a general practice acidifying both samples and standards/reference materials at room temperature is recommended.

It is also important to note that as is the case for $\delta^{18} \mathrm{O}$ values of water, $\delta^{18} \mathrm{O}$ values of phosphate are reported on the VSMOW scale. However, in an exception to the general rule that all $\delta^{18} \mathrm{O}$ values should be reported against VSMOW, $\delta^{18} \mathrm{O}$ values of carbonate are typically reported against VPDB. The $\delta^{18}$ OVPDB values of a given carbonate sample $\mathrm{X}\left(\mathrm{CO}_{3}{ }^{2-}[\mathrm{X}]\right)$ can be converted into its corresponding $\delta^{18}$ Ovsmow value using Eqn. 4 [82].

$\delta^{18} \mathrm{Ovsmow}_{\mathrm{V}}\left(\mathrm{CO}_{3}{ }^{2-}[\mathrm{X}]\right)=1.03091 \times \delta^{18} \mathrm{OVPDB}_{\mathrm{VPO}}\left(\mathrm{CO}_{3}{ }^{2-}[\mathrm{X}]\right)+30.91$

Eqn. 4

\section{Carbon Isotopic Composition of Bioapatite and Collagen}

The carbon isotopic composition of bioapatite - as well as the structural protein collagen - may also provide information on the past geographic life trajectory of an unidentified decedent. This is due to dietary preferences among human populations living in different regions of the globe. Variation in agricultural practices and cultural dietary habits have resulted in some populations, such as North Americans, consuming more $\mathrm{C}_{4}$ derived foods on average than populations living in Europe and Asia. This variation is reflected in the $\delta^{13} \mathrm{C}$ values of bone bioapatite, bone collagen, and tooth enamel.

Accounting for approximately $25 \%$ of all protein found in the body [83], collagen is a structural protein found in bone, tooth dentin, and skin. Unlike that of bioapatite, which reflects "bulk" diet $[84,85]$, the carbon isotopic composition of collagen reflects primarily the protein content of an individual's diet $[86,87]$. Analysis of both bioapatite and collagen can therefore provide more 
information on an individual's dietary choices than analysis of either material alone.

A practical application of the isotopic profiling of bioapatite and collagen concerns the identification of U.S. war dead. When expending resources to repatriate remains from past conflicts, it's important to determine whether those remains may have originated from North America. In her doctoral dissertation, Regan [88] noted that the $\delta^{13} \mathrm{C}$ values of tooth bioapatite "appear to be an excellent discriminator of natal origin between East Asian and American populations." This finding was corroborated by work on skeletal remains recovered by the Joint POW/MIA Accounting Command (JPAC, reorganized in January 2015 as the Defense POW/MIA Accounting Agency, DPAA). Results from 30 bone samples demonstrated that the $\delta^{13} \mathrm{C}$ values of bone bioapatite and bone collagen were significantly higher for U.S. Americans than native Asians [89].

\section{CASE STUDY}

The DPAA is charged with the recovery and identification of U.S. war dead, from the years including World War II up to through 1990. The DPAA is a multifaceted scientific and research agency within the U.S. government that employs both military and civilian personnel. Innovation of current scientific methods and procedures are part of DPAA's mission; in 2012, DPAA (then JPAC) began a collaboration with California State University, Chico to explore the use of stable isotope analysis for casualty resolution. This exploration has resulted in multiple papers and presentations showcasing the role that statistical treatments of isotopic data can have in the investigations of human remains [89-92]. In 2018, a fourth U.S. military member was identified in part through the use of stable isotope analysis. This case study presents an overview of that identification.

In the late summer of 1965, the pilot of a F101-C aircraft was on an observation mission of surface-to-air missile sites along coastal central Vietnam. During the mission, the lead aircraft was hit by ground fire and eventually disabled. After climbing to altitude, the pilot ejected and was blown inland toward a mountainous region of Vietnam. Voice radio contact was established with him on the ground for multiple hours. During the ensuing rescue operations, the pilot's radio contact eventually was lost and never regained, and he was not found.

Interviews with local Vietnamese nationals produced a few case leads in the early 1990s. Four witnesses lead U.S. government and host nation officials to where they claimed the pilot had been found and subsequently killed during a firefight. While no evidence to substantiate their claim was discovered, a later series of interviews with new witnesses lead to the eventual turnover of two small fragments of bone (a metacarpal and a phalanx) and several pieces of material evidence. Because the remains were too small for DNA testing in the 1990s, all evidentiary materials were curated pending scientific advancements. By 2017, mitochondrial DNA (mtDNA) testing was possibly viable; both skeletal fragments were sampled, and one yielded a sequence. While the comparison to the missing casualty was a match, the commonality of the mtDNA sequence data was such that an identification could not be easily substantiated, and additional evidence was needed. 
Stable isotope analyses of carbon and nitrogen of collagen and carbon and oxygen of bioapatite were attempted for both skeletal fragments. One sample yielded a poor $\mathrm{C} / \mathrm{N}$ ratio and isotopic compositions of collagen were not reported. The second sample had collagen $\delta^{13} \mathrm{C}$ and $\delta^{15} \mathrm{~N}$ values more similar to U.S. population means $(-16.3 \%$ and $+11.8 \%$, respectively) than the means of individuals from the Southeast Asian (SEA) countries of Vietnam and Laos ( $-19.6 \%$ and $+11.6 \%$, respectively). Likewise, the $\delta^{13} \mathrm{C}$ values of bioapatite extracted from both bone fragments were closest to the U.S. population mean $(-10.27 \%$ ) than samples that come from SEA (-14.43\%). (Data for population means were reported from Isolocate [93]; see below.)

As noted previously, Bartelink and colleagues [89] used discriminant function analysis to segregate U.S. service persons from SEA individuals following stable isotope analysis. Their protocol has been expanded into a proprietary computer database and Graphic User Interface, Isolocate, by Berg and Kenyhercz [93], which uses linear discriminate function analysis to discriminate between populations based on measured stable isotope ratios. When the case samples were compared statistically to U.S. and SEA populations, both bone fragments classified as being U.S. in origin (posterior probabilities of 0.938 and 0.963 ); the sample modelling had cross-validated accuracy rates of $84 \%$ and $91 \%$, respectively.

Interestingly, the oxygen isotope data were difficult to interpret. The bioapatite $\delta^{18} \mathrm{O}$ values of the two bone fragments were converted to drinking water $\delta^{18} \mathrm{O}$ values following Eqns. 2-4, mapped onto a tap water isoscape for the continental United States [29], and then compared to the casualty's home of record. The comparison was not particularly compelling as the nearest location with tap water $\delta^{18} \mathrm{O}$ values similar to those predicted was much further inland and north (about 300 miles) than the pilot's home of record. While not completely discordant, the oxygen isotopic profiles were not considered useful in identification of the pilot.

The identification of the pilot was constructed through a multi-pronged scientific investigation and series of conclusions. First, the two skeletal fragments were found in the location where the pilot purportedly had died. Second, both skeletal elements were human. Third, mtDNA was eventually extracted from one bone samples, but not the other, and that mtDNA matched the family reference specimen for the pilot. Fourth, both samples yielded similar apatite isotopic profiles, confirming an origin from the U.S., and not SEA (i.e., that the individual consumed a "Western" diet versus an "Eastern" diet). Finally, pilot-matching identification media, allegedly discovered near the remains location, was turned over to U.S. officials in 2017. While no single line of evidence was strong enough to be the basis of the identification, the totality of the evidence, including the isotopic data linking both bone fragments together, allowed for the clear resolution of the missing pilot.

Epilogue: When the pilot's identification was briefed to his surviving wife and daughter, the family noted one fact not present in his military service record - the family was living near Lyon, France for many years $(5+)$ prior to the pilot's call to active duty. The oxygen isotopic profiles of the remains, when converted from bioapatite $\delta^{18} \mathrm{O}$ values to drinking water $\delta^{18} \mathrm{O}$ values and compared with a precipitation isoscape for Europe (see Figure 1), were similar to those estimated for regions near Lyon, France. 


\section{Caveats for the Oxygen Isotope Analysis of Bone and Teeth}

Factors such as intra- and inter-individual variation contribute to the overall uncertainty of bioapatite $\delta^{18} \mathrm{O}$ values as well as bioapatite and collagen $\delta^{13} \mathrm{C}$ values. Isotopic variability can also be attributed to the sample preparation methods and analytical techniques used by different laboratories [94], which highlights the importance of applying well-controlled and standardized procedures when preparing and analyzing skeletal remains in forensic contexts. Another source of uncertainty is associated with the calculation of water $\delta^{18} \mathrm{O}$ values from measured bioapatite $\delta^{18} \mathrm{O}$ values [58,95]. Last but not least, as evident from the European $\delta^{18} \mathrm{O}$ isoscape shown in Figure 1 [26], multiple disparate regions in the world can share similar modeled $\delta^{18} \mathrm{O}$ values of water. Narrowing down the number of possible geographic points of origin even further requires additional exclusion criteria such as $\mathrm{Sr}$ or $\mathrm{Pb}$ isotopic profiles or other contextual information.

While tooth enamel once formed does not remodel, it is important to realize that both bone bioapatite and bone collagen do, which means different bones can yield information relating to different time periods in a person's life. Typical figures quoted in some textbooks give bone remodeling rates of 10 to $15 \%$ per year. However, these figures are generalized estimates, averaged over the entire human skeleton. In reality bone remodeling rates differ from bone to bone. Cancellous or trabecular bone, also referred to as spongy bone, remodels quickly while cortical or compact bone remodels at a slower rate [96]. Typical annual turnover rates for adult loadbearing compact bone such as mid-shaft femoral bone and spongy bone such as ribs are about $4 \%$ and $25 \%$ respectively, but there is variability depending on sex and the particular bone used for analysis [6,97-99]; see Table 1.

As mentioned previously, not all permanent teeth are equally "ideal" for forensic isotopic profiling. The tooth buds of permanent incisors and canines start formation around the time of birth, but crown growth is not typically complete until 4 to 5 years of age $[100,101]$. Therefore permanent teeth whose crown mineralization starts during the first year after birth will retain a record of changes in drinking water/diet due to the weaning process [102-105]. Regarding permanent teeth, first molars (M1 teeth) also start formation around the time of birth (year 0) while late erupting second molar tooth buds (M2 teeth) start formation around 2 to 3 years of age. Crown mineralization of M1 teeth is complete after 2.5 to 3 years whereas crown growth of second molars is complete only after 7 to 8 years of age. In contrast, crown mineralization of $3^{\text {rd }}$ molars (M3 teeth) starts 7 to 10 years after birth and completes between 12 to 16 years of age; second and third molars erupt between 11 to 13 and 17 to 21 years of age, respectively [100,101]. To avoid potential artifact signatures e.g. due to weaning, whenever possible late erupting molars M2 and M3 should be chosen for isotope analysis.

Last but not least, it is important to consider changes to the isotopic composition of bioapatite due to diagenesis, which can be caused by chemical or physicochemical processes such as prolonged submersion in (sea) water or burning (cremation or incineration) [106-110]. In particular, the $\delta^{18} \mathrm{O}$ values of the carbonate component of bone bioapatite are more likely to be affected by diagenesis given that the carbonate $\mathrm{C}-\mathrm{O}$ bond is susceptible to hydroxyl group exchange and thus net oxygen "exchange" with water. Chemical alterations typically increase with age and samples from archaeological settings can be severely impacted. However, bone and teeth encountered in most "modern" investigations should be relatively unaffected by diagenesis. 


\section{Shorter-term "Memory" Tissues: Hair and Nail}

The fact that human hair and nail grow more or less continuously and at known rates can be exploited to obtain chronological information useful for reconstructing an unidentified decedent's recent life history. This reconstructed record can aid with victim identification but also has applications in the investigation of human trafficking and terrorism. While methods to categorize and compare hair on the basis of morphology, taxonomy, chemical composition, and DNA have been established and used for more than 20 years, the ability to investigate recent changes in geographical movement and dietary intake based on the sequential isotopic analysis of hair and nail is largely due to the continued efforts of a handful of research groups during the last decade $[6,14,16,17,25,26,30-32,63-65,69,111-116]$.

Analogous to the forensic application of isotopic profiling to bone and teeth, isotopic analysis of hair and nail is focused on the relationship between water source and tissue-specifically $\mathrm{H}$ and O isotopic compositions - since this can provide information on a person's recent geographic history. Analyzing hair and nail for $\mathrm{C}$ and $\mathrm{N}$ isotopic compositions can reveal recent changes in diet that may coincide with a change in $\mathrm{H}$ and/or $\mathrm{O}$ isotopic composition as a result of movement from one location to another. In another analogy to the forensic isotopic analysis of bone and teeth, the current knowledge base regarding isotopic profiling of hair and nail from modern people owes a lot to research in bioarcheology and anthropology [13,21,41-43,62,117-119].

Hair and nail share a number of common characteristics. The major constituent of both by weight is a family of fibrous structural protein called collectively "keratin." Both hair and nail are static by nature. That is, while both are being continuously formed, neither keratinized hair nor nail is a living tissue. Once formed, the keratin proteins are isolated from the rest of the body and do not remodel. Human scalp hair grows at a rate of $7-10 \mathrm{~mm} / \mathrm{month}$ and beard hair grows at a rate of $12 \mathrm{~mm} / \mathrm{month}$, while the growth rate of pubic hair is typically $6 \mathrm{~mm} / \mathrm{month}$ [120]. However, these figures should not be taken to mean every single strand of hair on a person's body is growing at a constant rate all the time. Hair grows by active mitosis in the hair follicle and each follicle goes through a cyclic pattern of activity that produces 20 to 30 hairs during its lifetime. On the average human scalp at any given time, $90 \%$ of the follicles are in anagen, the growth phase, which lasts 6-10 years. The anagen phase is followed by catagen, the regression phase, lasting 14-21 days for scalp hair with $\sim 2 \%$ of the follicles on a normal scalp being in this phase. Telogen is the final phase during which hair is shed and it lasts 30-90 days (accounting for the balance of $8 \%$ of follicles) for scalp hair, but as long as three years for pubic and chest hairs. As an important practical consequence of this, a lock of hair comprised of 50-100 individual strands should be sampled whenever practical to ensure that for any given analyzed segment the majority of hair was in the anagen phase thus yielding data representative of recent life history. In cases where few hair strands are analyzed, it may possible to use inverse models to deconvolute the signal [121].

\section{Hydrogen Isotopic Composition of Hair and Nail}

Hydrogen incorporated into human hair and nail is recruited from two main precursor pools: "liquid" hydrogen, or hydrogen bound in water (in whatever form), and "solid" hydrogen, or hydrogen in food either stored as water (in fruits and vegetables) or chemically bound in carbohydrates and proteins. Based on a tracer experiment [62], there is evidence suggesting that approximately $30 \%$ of hydrogen preserved in human hair is directly derived from ingested water 
with the remainder is derived from hydrogen present in food. For this reason, hydrogen and, similarly, oxygen isotopic compositions of human hair and nail are highly correlated to the isotopic composition of drinking water [16,26,30]. To the best of our knowledge, only one research group to date has studied the hydrogen isotopes of human nail as a non-invasive source of information about a person's recent geographic life history [16,30] and reported an equation correlating $\delta^{2} \mathrm{H}$ values of water with $\delta^{2} \mathrm{H}$ values of nail. When paired hair and nail samples from 36 people in different locations were compared, the slope of the $\delta^{2} \mathrm{H}_{\text {water }} / \delta^{2} \mathrm{H}_{\text {nail }}$ correlation equation was 0.37 , which was shallower than the slope of 0.54 for the $\delta^{2} \mathrm{H}_{\text {water }} / \delta^{2} \mathrm{H}_{\text {hair }}$ correlation equation obtained from the same sample population [30]. This notwithstanding, the $\delta^{2} \mathrm{H}_{\text {water }} / \delta^{2} \mathrm{H}_{\text {nail }}$ correlation showed a coefficient of determination $\left(\mathrm{R}^{2}\right)$ of 0.6 .

Assuming 30\% of the hydrogen in human hair is directly derived from "liquid" hydrogen [62] it follows that populations with $\delta^{2} \mathrm{H}_{\text {water }} / \delta^{2} \mathrm{H}_{\text {hair }}$ correlation equations that have slopes near 0.3 source their "liquid" hydrogen locally or at least regionally, while the contribution of "solid" hydrogen comes from mixed but predominantly non-local food sources. People living in North America are a prime example for such a population [26]. Even if food is purchased at the local grocery store, its ultimate origin may have been the "global" supermarket. A study by O'Brien et al. clearly demonstrated this fact: no matter where a selection of food was purchased in various states of the U.S. (including Alaska), its isotopic composition was essentially the same [122].

In contrast, any increase of the $\delta^{2} \mathrm{H}_{\text {water }} / \delta^{2} \mathrm{H}_{\text {hair }}$ correlation slope beyond 0.3 would be indicative of an increased uptake of "solid" hydrogen from food of local or regional origin. In simple terms, the more local (and seasonal) the origin of food consumed by a given population, the more positive the slope of the $\delta^{2} \mathrm{H}_{\text {water }} / \delta^{2} \mathrm{H}_{\text {hair }}$ correlation equation should be. Studies of populations with different consumer behavior did indeed yield different slopes for the corresponding $\delta^{2} \mathrm{H}_{\text {water }}$ / $\delta^{2} \mathrm{H}_{\text {hair }}$ correlation equations [30-32] with the hair/water correlation equation of people from indigenous ("non-globalized") populations having the steepest slope of 0.78 [31].

\section{Caveats for the Hydrogen Isotope Analysis of Hair and Nail}

Isotopic profiling of human hair has received a good deal of attention in the past decade and a rich repository of published knowledge exists on the particular challenge that is $\mathrm{H}$ isotope abundance analysis of hair in general $[111,123,124]$ and of human hair in a forensic contexts in particular $[6,26,30,62,69,125-127]$. Between 9 and 15\% of $\mathrm{H}$ covalently bound in hydroxyl, thiol, amino, and free carboxyl functional groups will exchange with $\mathrm{H}$ in ambient humidity or moisture $[30,62,69,111,123,124]$. The effect of this exchange depends not only on sample nature but also on three additional factors. Firstly, hair samples handled and analyzed at different times (and temperatures) may have exchanged hydrogen with ambient humidity of different isotopic composition at different rates of exchange. Samples will be contaminated with traces of ambient moisture that will make a contribution to the overall measured hydrogen isotopic composition if they are not, secondly, thoroughly dried prior to analysis; and thirdly, transferred into a hermetically sealed autosampler with a protective atmosphere of dry helium [69,111,123,124]. A critical review published in 2013 describes some methodological approaches for determining "true" $\delta^{2} \mathrm{H}$ values - the $\delta^{2} \mathrm{H}$ values of the non-exchangeable or intrinsic $\mathrm{H}$ fraction of proteins such as keratin [128].

Following stable isotope analysis, sample $\delta$ values must not only be linked to the zero-point of 
the appropriate internationally agreed $\delta$ scale but also be aligned to the size of the relevant $\delta$ scale through calibration (or normalization) to compensate for an effect called scale compression [129-131]. If a secondary international measurement standard defines the size of a $\delta$ scale, as is the case with the VSMOW/SLAP scale for ${ }^{2} \mathrm{H}, \delta$ values should be normalized using both standards as scale anchors, or two reference materials (two end points) whose $\delta$ values adequately cover the size of the $\delta$ scale. Primary reference materials (RMs) provide the zeropoints of the relevant $\delta$ scale (e.g., VSMOW2) while secondary RMs (e.g., SLAP2) are natural or synthetic compounds that have been carefully calibrated relative to the primary RMs. Tertiary RMs are compounds that have been calibrated using secondary RMs; available from commercial organizations and universities, these materials often provide a better matrix match to samples. Laboratories can also calibrate in-house standards using primary (when available) or secondary RMs that are matrix-matched to the samples commonly encountered during casework.

Good practice guidelines for isotope ratio measurements and reporting results thereof strongly recommend the use of two end-points to construct a normalization equation of the form $\delta_{\text {accepted }}=$ $s \times \delta_{\text {measured }}+b[130]$. The slope of the regression line $(s)$ is referred to as the expansion factor, stretch factor, or simply "stretch" and the intercept $(b)$ as the additive correction factor, shift factor, or simply "shift." The practical consequence of not observing good practice guidelines with regards to scale normalization can result in measured $\delta$ values that may be consistent within a single laboratory or working group, but not comparable to data from other laboratories. It is crucial for comparability, traceability, and repeatability that all measured $\delta$ values be normalized using the same approach and scale. While scale normalization of measured $\delta$ values based on two end-points is recommended for all non-metal element isotope analyses, it is of particular importance for hydrogen isotope analysis due to the large dynamic scale compression associated with $\mathrm{H}$ isotope abundances.

\section{Carbon and Nitrogen Isotopic Compositions of Hair and Nail}

Unlike $\delta^{2} \mathrm{H}$ or $\delta^{18} \mathrm{O}$ values, which can be used as indicators of geographic provenance, $\delta^{13} \mathrm{C}$ and/or $\delta^{15} \mathrm{~N}$ values of hair and nail provide general insights into dietary habits, which may or may not vary based on geography $[32,34,35]$. In this application, $\delta^{13} \mathrm{C}$ values may be used as a contextual qualifier or exclusion criterion. This can be especially useful when interpreting hydrogen and oxygen isotopic profiles with regards to geographic point-of-origin or change in geographic location when observed $\delta^{2} \mathrm{H}$ or $\delta^{18} \mathrm{O}$ values are not unique to one particular region but are consistent with several regions of the world. Here isotope ratio analysis of other elements (e.g. S, Sr, and/or Pb) may be additionally helpful [24,132,133].

We note that published data on the carbon and nitrogen isotopic compositions of human nail are few and far between but do demonstrate that these tissues in principle reflect the isotopic composition of diet in a similar way as human hair $[14,16,30,69,125,134]$. However, there is a difference in $\delta^{13} \mathrm{C}$ values between paired hair and nail samples on the order of -0.5 to $-0.3 \%$, while the difference in $\delta^{15} \mathrm{~N}$ values between matching hair and nail samples from the same individuals is on the order of +0.5 to $+1.0 \%$ o $[14,16,32,69,134]$.

As summarized previously, an increase in $\mathrm{C}_{4}$ derived protein in an individual's diet is typically associated with an increase in $\delta^{13} \mathrm{C}$ values of hair and nail. For example, the preponderance of $\mathrm{C}_{4}$ plants in the North American diet is reflected in the higher, on average, $\delta^{13} \mathrm{C}$ values of human 
hair from North American citizens as compared to European citizens [35]. An increase in quantity of consumed animal protein also impacts the $\delta^{15} \mathrm{~N}$ values of keratinous tissues. Hair or nail $\delta^{15} \mathrm{~N}$ values within a range of approximately +8 to $+10 \%$ are usually indicative of an omnivorous or an ovolactovegetarian diet $[14,16,20,32]$ while $\delta^{15} \mathrm{~N}$ values of about +7 to $+8 \%$ are indicative of a vegan diet that includes no animal protein whatsoever. In contrast, $\delta^{15} \mathrm{~N}$ values in excess of $+10 \%$ are typically indicative of a diet rich in animal protein. For individuals at the apex of a food web, such as Inuit eating protein from predatory species, $\delta^{15} \mathrm{~N}$ values as high as $+18.2 \%$ have been reported [31,69].

\section{Caveats for the Carbon and Nitrogen Isotope Analysis of Hair and Nail}

As a word of caution, elevated tissue $\delta^{13} \mathrm{C}$ values do not necessarily always denote a high dietary uptake of $\mathrm{C}_{4}$ plant derived carbon. Two additional factors to consider when interpreting tissue $\delta^{13} \mathrm{C}$ values include: (1) that the isotopic shift between diet $\delta^{13} \mathrm{C}$ values and tissue $\delta^{13} \mathrm{C}$ values is tissue dependent [14,69], and (2) that the isotopic shift associated with trophic level can result in higher-than-expected $\delta^{13} \mathrm{C}$ values for top predators. For example, Inuit subsist on a protein-rich diet from marine sources as well as predatory animals. Even at the lowest trophic level, marine food webs typically exhibit higher $\delta^{13} \mathrm{C}$ values than terrestrial food webs. Furthermore, consuming meat from predators puts the Inuit on the trophic level of a tertiary consumer, or a consumer of carnivores. As a consequence of their unique position in the food web, $\delta^{13} \mathrm{C}$ values of about $-15 \%$ have been reported for Inuit hair (Canada) [31,69]. By comparison, similarly high $\delta^{13} \mathrm{C}$ values are found in hair from people living in South Africa, though here these elevated $\delta^{13} \mathrm{C}$ values result primarily from a high level of $\mathrm{C}_{4}$ plant derived carbon in the South African staple diet.

\section{Strontium and Lead Isotopic Compositions of Human Tissue}

Unlike light element non-metal elements, which are the main constituent of the keratin structure, heavy element metal elements such as $\mathrm{Sr}$ and $\mathrm{Pb}$ are only present in trace concentrations in these tissues [23]. Previous studies have demonstrated that the ${ }^{87} \mathrm{Sr} /{ }^{86} \mathrm{Sr}$ ratios of keratin tissues of humans correlate strongly with that of water sources [24,47,49,64,135], although the contribution of different endogenous sources (food and water ingestion) and exogenous sources (surface exposure) to the abundance and isotopic composition of $\mathrm{Sr}$ and $\mathrm{Pb}$ in keratin is not fully understood. A portion of $\mathrm{Sr}$ and $\mathrm{Pb}$ in keratin tissues originate from endogenous sources and reflect the isotopic signatures of the food and water ingested. However, both elements are soluble in water and can diffuse and exchange through the keratin structure when wetted [23]. This diffusion can alter the abundance and potentially the isotopic composition. Humans with different bathing habits might exchange their $\mathrm{Sr}$ and their $\mathrm{Pb}$ at different rates, complicating the interpretation of provenance. Exchange also depends on the structure of the tissue. For example, the ${ }^{87} \mathrm{Sr} /{ }^{86} \mathrm{Sr}$ ratio of fingernails from travelers uniformly reflects the isotopic composition of the wash water at the last location visited [64] while the ${ }^{87} \mathrm{Sr} /{ }^{86} \mathrm{Sr}$ ratios of horsehair reflect movements of individuals [136]. Keratin in nail is not protected by cuticle scales, which could favor faster diffusion and exchange during wetting of nail versus hair. Hands are also wetted more frequently than hair, which could explain the dominance of exogenous $\mathrm{Sr}$ in nails.

To our knowledge, little isotopic data exist to explain the $\mathrm{Pb}$ isotopic variation in hair and/or nails $[47,135,137]$. However, it is understood that identifying and separating the endogenous and exogenous portion of $\mathrm{Pb}$ - and $\mathrm{Sr}$ - in keratin tissues is critical prior to interpreting isotopic 
profiles. Wetting frequency and residence time of metals in keratin in wet environment should be considered. Consider forensic cases where a body is found in a wet environment or following exposure to wet conditions (e.g., rain, snow, or soil water) - in these cases, it is possible that the keratin tissues will have exchanged $\mathrm{Sr}$ and $\mathrm{Pb}$ with local water sources and not necessarily reflect geographic history.

In contrast to hair, $\mathrm{Sr}$ and $\mathrm{Pb}$ in both bone and teeth primarily reflect $\mathrm{Sr}$ and $\mathrm{Pb}$ present in ingested food and drink $[10,55,61,138-140]$. This does not mean that these isotopic profiles are completely free from confounding influences. For instance, a predominantly marine sourced diet may shift terrestrial ${ }^{87} \mathrm{Sr} /{ }^{86} \mathrm{Sr}$ ratios that could be exploited forensically towards the range of ${ }^{87} \mathrm{Sr} /{ }^{86} \mathrm{Sr}$ ratios found in seawater. An analogous argument could be made for $\mathrm{Pb}$ isotope ratios from influences such as lead emission from anthropogenic sources. However, with careful consideration of the likelihood and potential magnitude of such confounding factors, measurement of $\mathrm{Sr}$ and/or $\mathrm{Pb}$ isotope ratios can help narrow down potential regions of geographic origin when combined with light element isotope signatures of hydrogen and/or oxygen when multiple disparate regions in the world share similar modeled $\delta^{2} \mathrm{H}$ and/or $\delta^{18} \mathrm{O}$ values of source water $[60,141]$.

\section{Conclusion}

The isotopic profiles of human tissues such as bone, teeth, hair, and nail hold great potential for forensic investigations by providing valuable information regarding an unidentified decedent's life history that cannot be obtained by any other analytical method. Profiling based on temporal records of isotopes in human tissues can unlock valuable information about a person's life history if interpreted in context and with cognizance of potentially confounding factors. While isotopic profiling alone will not be able to "identify" a person directly, it holds the potential to focus an investigation, to provide corroborating information that supports a particular line of enquiry to the exclusion of others, and to act as a screening tool for repatriation of victims of multi-national, multi-ethnic mass disasters - thus ultimately helping to assert a person's most basic human right, their right to their personal identity. 
Table 1 Chronology of stable isotope records in human tissues. ${ }^{a}$

\begin{tabular}{|c|c|c|c|c|c|}
\hline Tissue & Time-frame & Sample & Component & $\begin{array}{l}\text { Stable } \\
\text { isotope/s }\end{array}$ & Information \\
\hline \multirow[t]{2}{*}{ Scalp hair } & $\begin{array}{l}\text { Months prior to } \\
\text { death }\end{array}$ & $\begin{array}{l}5 \mathrm{~mm} \text { hair } \\
\text { segments }\end{array}$ & $\begin{array}{l}\text { Keratin } \\
\text { (whole hair) }\end{array}$ & ${ }^{2} \mathrm{H} ;{ }^{18} \mathrm{O}$ & $\begin{array}{l}\text { Geographic } \\
\text { history }^{b}\end{array}$ \\
\hline & $\begin{array}{l}5 \mathrm{~mm}=0.5 \\
\text { month }\end{array}$ & & & ${ }^{13} \mathrm{C} ;{ }^{15} \mathrm{~N} ;{ }^{34} \mathrm{~S}$ & Diet; lifestyle \\
\hline Fingernail & $\begin{array}{l}\text { Months prior to } \\
\text { death }\end{array}$ & $\begin{array}{l}3 \mathrm{~mm} \text { nail } \\
\text { segments }\end{array}$ & $\begin{array}{l}\text { Keratin } \\
\text { (whole nail) }\end{array}$ & ${ }^{2} \mathrm{H}$ & $\begin{array}{l}\text { Geographic } \\
\text { history }^{b}\end{array}$ \\
\hline (thumb) & $3 \mathrm{~mm}=1$ month & & & ${ }^{13} \mathrm{C}:{ }^{15} \mathrm{~N} \cdot{ }^{34} \mathrm{~S}$ & Diet; lifestyle \\
\hline Toenail & $\begin{array}{l}\text { Months prior to } \\
\text { death }\end{array}$ & $\begin{array}{l}1 \mathrm{~mm} \text { nail } \\
\text { segments }\end{array}$ & $\begin{array}{l}\text { Keratin } \\
\text { (whole nail) }\end{array}$ & ${ }^{2} \mathrm{H}$ & $\begin{array}{l}\text { Geographic } \\
\text { history }^{b}\end{array}$ \\
\hline (big toe) & $1 \mathrm{~mm}=1 \mathrm{month}$ & & & ${ }^{13} \mathrm{C} \cdot{ }^{15} \mathrm{~N} \cdot{ }^{34} \mathrm{~S}$ & Diet; lifestyle \\
\hline $\begin{array}{l}\text { Cortical } \\
\text { bone }\end{array}$ & $\begin{array}{l}10 \text { to } 15 \text { years } \\
\text { prior to death }\end{array}$ & $\begin{array}{l}\text { Mid-shaft } \\
\text { bone }^{c}\end{array}$ & $\begin{array}{l}\text { Carbonate } \\
\text { (bioapatite) }\end{array}$ & ${ }^{13} \mathrm{C} ;{ }^{18} \mathrm{O}$ & $\begin{array}{l}\text { Diet; } \\
\text { geographic } \\
\text { history }\end{array}$ \\
\hline \multirow[t]{2}{*}{ (humerus) } & $\begin{array}{l}\text { approx. } 10 \text { years } \\
\text { (average) }\end{array}$ & (diaphysis) & $\begin{array}{l}\text { Phosphate } \\
\text { (bioapatite) }\end{array}$ & ${ }^{18} \mathrm{O}$ & $\begin{array}{l}\text { Geographic } \\
\text { history }\end{array}$ \\
\hline & & & $\begin{array}{l}\text { Collagen } \\
\text { fraction }\end{array}$ & ${ }^{13} \mathrm{C} ;{ }^{15} \mathrm{~N} ;{ }^{34} \mathrm{~S}$ & Diet; lifestyle \\
\hline $\begin{array}{l}\text { Cortical } \\
\text { bone }\end{array}$ & $\begin{array}{l}15 \text { to } 20 \text { years } \\
\text { prior to death }\end{array}$ & $\begin{array}{l}\text { Mid-shaft } \\
\text { bonec }^{c}\end{array}$ & $\begin{array}{l}\text { Carbonate } \\
\text { (bioapatite) }\end{array}$ & ${ }^{13} \mathrm{C} ;{ }^{18} \mathrm{O}$ & $\begin{array}{l}\text { Diet; } \\
\text { geographic } \\
\text { history }\end{array}$ \\
\hline \multirow[t]{2}{*}{ (tibia) } & $\begin{array}{l}\text { approx. } 15 \text { years } \\
\text { (average) }\end{array}$ & (diaphysis) & $\begin{array}{l}\text { Phosphate } \\
\text { (bioapatite) }\end{array}$ & ${ }^{18} \mathrm{O}$ & $\begin{array}{l}\text { Geographic } \\
\text { history }\end{array}$ \\
\hline & & & $\begin{array}{l}\text { Collagen } \\
\text { fraction }\end{array}$ & ${ }^{13} \mathrm{C} ;{ }^{15} \mathrm{~N} ;{ }^{34} \mathrm{~S}$ & Diet; lifestyle \\
\hline $\begin{array}{l}\text { Cortical } \\
\text { bone }\end{array}$ & $\begin{array}{l}20 \text { to } 25 \text { years } \\
\text { prior to death }\end{array}$ & $\begin{array}{l}\text { Mid-shaft } \\
\text { bone }^{c}\end{array}$ & $\begin{array}{l}\text { Carbonate } \\
\text { (bioapatite) }\end{array}$ & ${ }^{13} \mathrm{C} ;{ }^{18} \mathrm{O}$ & $\begin{array}{l}\text { Diet; } \\
\text { geographic } \\
\text { history }\end{array}$ \\
\hline \multirow[t]{2}{*}{ (femur) } & $\begin{array}{l}\text { approx. 20+ } \\
\text { years (average) }\end{array}$ & (diaphysis) & $\begin{array}{l}\text { Phosphate } \\
\text { (bioapatite) }\end{array}$ & ${ }^{18} \mathrm{O}$ & $\begin{array}{l}\text { Geographic } \\
\text { history }\end{array}$ \\
\hline & & & $\begin{array}{l}\text { Collagen } \\
\text { fraction }\end{array}$ & ${ }^{13} \mathrm{C} ;{ }^{15} \mathrm{~N} ;{ }^{34} \mathrm{~S}$ & Diet; lifestyle \\
\hline Teeth & $\begin{array}{l}\text { Childhood/ } \\
\text { adolescence }\end{array}$ & Enamel $^{c}$ & $\begin{array}{l}\text { Carbonate } \\
\text { (bioapatite) }\end{array}$ & ${ }^{13} \mathrm{C} ;{ }^{18} \mathrm{O}$ & $\begin{array}{l}\text { Geographic } \\
\text { history }\end{array}$ \\
\hline (M2, M3) & $\begin{array}{l}6 \text { to } 15 \text { years of } \\
\text { age }\end{array}$ & & $\begin{array}{l}\text { Phosphate } \\
\text { (bioapatite) }\end{array}$ & ${ }^{18} \mathrm{O}$ & $\begin{array}{l}\text { Geographic } \\
\text { history }\end{array}$ \\
\hline
\end{tabular}

-Time-frames given for bone are approximate and should not be mistaken for fixed points in time. For further information on bone remodeling rates refer to Meier-Augenstein and Fraser (2008); Martin et al. (2015); Hedges et al. (2007); Pearson and Lieberman (2004). ${ }^{b}$ Analysis of $\mathrm{Sr}$ isotopes in hair and nail can provide complementary information on geographic history: see Tipple et al. (2013, 2018); Vautour et al. (2015); Mancuso and Ehleringer (2018), Font et al. (2012).

"Bone and enamel can also be analysed as bulk or "whole" material for Sr and Pb isotopes: see Font et al. (2015); Kimmerle and Kamenov (2015); Kamenov and Curtis (2017); Kamenov (2008). 


\section{Figures}

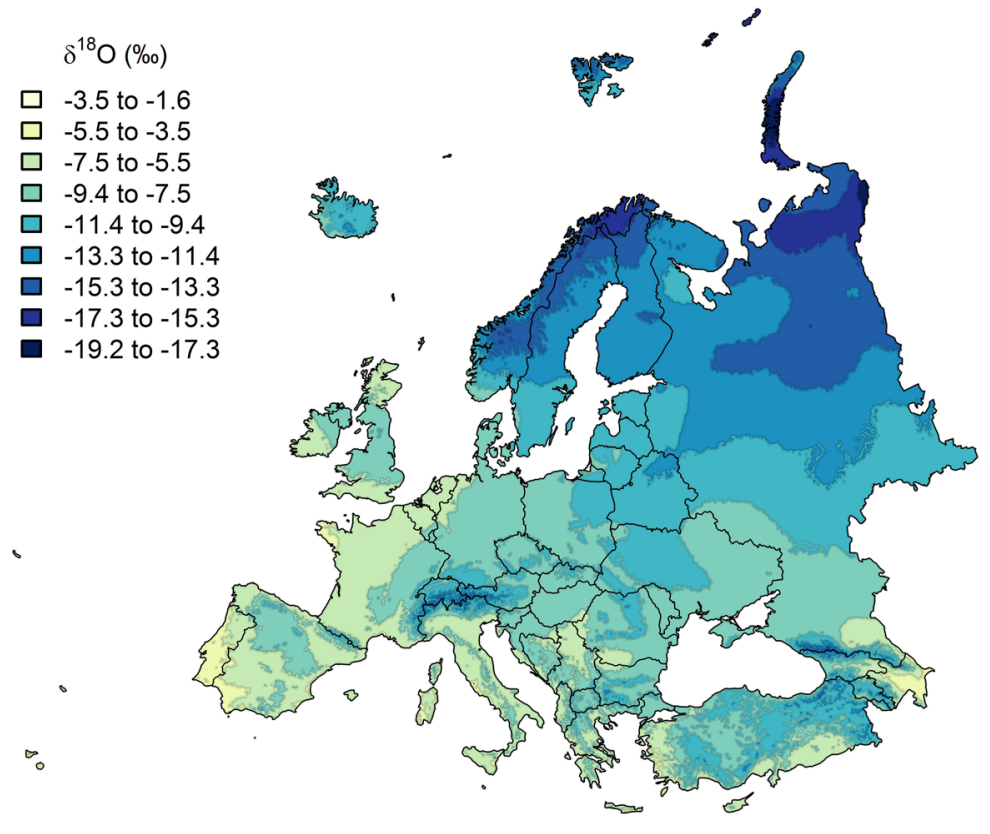

http://waterisotopes.org

Figure 1. Example isoscape, presenting predicated mean annual precipitation $\delta^{18} \mathrm{O}$ values for Europe. Image reprinted with permission from waterisoscapes.org. 


\section{References}

1. Morgan, O.W., Sribanditmongkol, P., Perera, C., Sulasmi, Y., Van Alphen, D., and Sondorp, E. (2006) Mass fatality management following the South Asian tsunami disaster: Case studies in Thailand, Indonesia, and Sri Lanka. PLoS Medicine, 3 (6), e195.

2. Wilkinson, C. (2007) Facial anthropology and reconstruction, in Forensic Human Identification (eds.Thompson, T., and Black, S.), CRC Press, pp. 231-270.

3. Stephan, C.N., and Claes, P. (2016) Craniofacial identification: Techniques of facial approximation and craniofacial superimposition, in Handbook of forensic anthropology and archaeology (eds.Blau, S., and Ubelaker, D.H.), Routledge, pp. 402-415.

4. Starkie, A. (2011) Body modifications as a tool to aid human identification.

5. West, J.B., Bowen, G.J., Cerling, T.E., and Ehleringer, J.R. (2006) Stable isotopes as one of nature's ecological recorders. Trends in Ecology \& Evolution, 21 (7), 408-414.

6. Meier-Augenstein, W., and Fraser, I. (2008) Forensic isotope analysis leads to identification of a mutilated murder victim. Science \& Justice, 48 (3), 153-159.

7. Coplen, T.B. (2011) Guidelines and recommended terms for expression of stable-isotoperatio and gas-ratio measurement results. Rapid Communications in Mass Spectrometry, 25 (17), 2538-2560.

8. Crowley, B.E., Miller, J.H., and Bataille, C.P. (2017) Strontium isotopes $\left({ }^{87} \mathrm{Sr} /{ }^{86} \mathrm{Sr}\right)$ in terrestrial ecological and palaeoecological research: Empirical efforts and recent advances in continental-scale models. Biological Reviews, 92 (1), 43-59.

9. Keller, A.T., Regan, L.A., Lundstrom, C.C., and Bower, N.W. (2016) Evaluation of the efficacy of spatiotemporal $\mathrm{Pb}$ isoscapes for provenancing of human remains. Forensic Science International, 261, 83-92.

10. Beard, B.L., and Johnson, C.M. (2000) Strontium isotope composition of skeletal material can determine the birth place and geographic mobility of humans and animals. Journal of Forensic Sciences, 45 (5), 1049-1061.

11. Faure, G., and Mensing, T.M. (2005) Isotopes: Principles and Applications, Wiley, Hoboken, N.J.

12. Bataille, C.P., and Bowen, G.J. (2012) Mapping ${ }^{87} \mathrm{Sr} /{ }^{86} \mathrm{Sr}$ variations in bedrock and water for large scale provenance studies. Chemical Geology, 304-305, 39-52.

13. O’Connell, T.C., and Hedges, R.E.M. (1999) Isotopic comparison of hair and bone: Archaeological analyses. Journal of Archaeological Science, 26 (6), 661-665.

14. O’Connell, T.C., Hedges, R.E.M., Healey, M.A., and Simpson, A.H.R.W. (2001) Isotopic comparison of hair, nail and bone: Modern analyses. Journal of Archaeological Science, 28 (11), 1247-1255.

15. Richards, M.P., Fuller, B.T., Sponheimer, M., Robinson, T., and Ayliffe, L. (2003) Sulphur isotopes in palaeodietary studies: A review and results from a controlled feeding experiment. International Journal of Osteoarchaeology, 13 (1-2), 37-45.

16. Fraser, I., Meier-Augenstein, W., and Kalin, R.M. (2006) The role of stable isotopes in human identification: a longitudinal study into the variability of isotopic signals in human hair and nails. Rapid Communications in Mass Spectrometry, 20 (7), 1109-1116.

17. Bol, R., Marsh, J., and Heaton, T.H.E. (2007) Multiple stable isotope $\left({ }^{18} \mathrm{O},{ }^{13} \mathrm{C},{ }^{15} \mathrm{~N}\right.$ and $\left.{ }^{24} \mathrm{~S}\right)$ analysis of human hair to identify the recent migrants to a rural community in SW England. Rapid Communications in Mass Spectrometry, 21 (18), 2951-2954. 
18. Dickson, J.H., Oeggl, K., Holden, T.G., Handley, L.L., O’Connell, T.C., and Preston, T. (2000) The omnivorous Tyrolean Iceman: Colon contents (meat, cereals, pollen, moss and whipworm) and stable isotope analyses. Philosophical Transactions of the Royal Society B: Biological Sciences, 355 (1404), 1843-1849.

19. Macko, S.A., Engel, M.H., Andrusevich, V., Lubec, G., O’Connell, T.C., and Hedges, R.E.M. (1999) Documenting the diet in ancient human populations through stable isotope analysis of hair. Philosophical Transactions of the Royal Society B: Biological Sciences, 354 (1379), 65-76.

20. O'Connell, T.C., and Hedges, R.E.M. (1999) Investigations into the effect of diet on modern human hair isotopic values. American Journal of Physical Anthropology, 108 (4), 409-425.

21. Wilson, A.S., Taylor, T., Ceruti, M.C., Chavez, J.A., Reinhard, J., Grimes, V., MeierAugenstein, W., Cartmell, L., Stern, B., Richards, M.P., Worobey, M., Barnes, I., and Gilbert, M.T.P. (2007) Stable isotope and DNA evidence for ritual sequences in Inca child sacrifice. Proceedings of the National Academy of Sciences, 104 (42), 16456-16461.

22. Richards, M.P., Fuller, B.T., and Hedges, R.E.M. (2001) Sulphur isotopic variation in ancient bone collagen from Europe: Implications for human palaeodiet, residence mobility, and modern pollutant studies. Earth and Planetary Science Letters, 191 (3-4), 185-190.

23. Hu, L. (2015) Spatial concentrations of trace elements in keratin.

24. Tipple, B.J., Chau, T., Chesson, L.A., Fernandez, D.P., and Ehleringer, J.R. (2013) Isolation of strontium pools and isotope ratios in modern human hair. Analytica Chimica Acta, 798, 64-73.

25. Bowen, G.J., Winter, D.A., Spero, H.J., Zierenberg, R.A., Reeder, M.D., Cerling, T.E., and Ehleringer, J.R. (2005) Stable hydrogen and oxygen isotope ratios of bottled waters of the world. Rapid Communications in Mass Spectrometry, 19 (23), 3442-3450.

26. Ehleringer, J.R., Bowen, G.J., Chesson, L.A., West, A.G., Podlesak, D.W., and Cerling, T.E. (2008) Hydrogen and oxygen isotope ratios in human hair are related to geography. Proceedings of the National Academy of Sciences, 105 (8), 2788-2793.

27. van der Veer, G., Voerkelius, S., Lorentz, G., Heiss, G., and Hoogewerff, J.A. (2009) Spatial interpolation of the deuterium and oxygen-18 composition of global precipitation using temperature as ancillary variable. Journal of Geochemical Exploration, 101 (2), 175184.

28. Bowen, G.J., and Revenaugh, J. (2003) Interpolating the isotopic composition of modern meteoric precipitation. Water Resources Research, 39 (10).

29. Bowen, G.J., Ehleringer, J.R., Chesson, L.A., Stange, E., and Cerling, T.E. (2007) Stable isotope ratios of tap water in the contiguous United States. Water Resources Research, 43 (3), W03419.

30. Fraser, I., and Meier-Augenstein, W. (2007) Stable ${ }^{2} \mathrm{H}$ isotope analysis of modern-day human hair and nails can aid forensic human identification. Rapid Communications in Mass Spectrometry, 21 (20), 3279-3285.

31. Bowen, G.J., Ehleringer, J.R., Chesson, L.A., Thompson, A.H., Podlesak, D.W., and Cerling, T.E. (2009) Dietary and physiological controls on the hydrogen and oxygen isotope ratios of hair from mid-20th century indigenous populations. American Journal of Physical Anthropology, 139 (4), 494-504.

32. Thompson, A.H., Chesson, L.A., Podlesak, D.W., Bowen, G.J., Cerling, T.E., and Ehleringer, J.R. (2010) Stable isotope analysis of modern human hair collected from Asia 
(China, India, Mongolia, and Pakistan). American Journal of Physical Anthropology, 141 (3), 440-451.

33. Podlesak, D.W., Bowen, G.J., O’Grady, S., Cerling, T.E., and Ehleringer, J.R. (2012) $\delta^{2} H$ and $\delta^{18} \mathrm{O}$ of human body water: A GIS model to distinguish residents from non-residents in the contiguous USA. Isotopes in Environmental and Health Studies, 48 (2), 259-279.

34. Valenzuela, L.O., Chesson, L.A., O'Grady, S.P., Cerling, T.E., and Ehleringer, J.R. (2011) Spatial distributions of carbon, nitrogen and sulfur isotope ratios in human hair across the central United States. Rapid Communications in Mass Spectrometry, 25 (7), 861-868.

35. Valenzuela, L.O., Chesson, L.A., Bowen, G.J., Cerling, T.E., and Ehleringer, J.R. (2012) Dietary heterogeneity among Western industrialized countries reflected in the stable isotope ratios of human hair. PLoS ONE, 7 (3), e34234.

36. Chesson, L.A., Podlesak, D.W., Thompson, A.H., Cerling, T.E., and Ehleringer, J.R. (2008) Variation of hydrogen, carbon, nitrogen, and oxygen stable isotope ratios in an American diet: Fast food meals. Journal of Agricultural and Food Chemistry, 56 (11), 4084-4091.

37. Chesson, L.A., Ehleringer, J.R., and Cerling, T.E. (2012) Light-element isotopes (H, C, N, and $\mathrm{O}$ ) as tracers of human diet: A case study on fast food meals, in Handbook of Environmental Isotope Geochemistry (eds.Baskaran, M.), Springer Berlin Heidelberg, Berlin, Heidelberg, pp. 707-723.

38. Brooks, J.R., Buchmann, N., Phillips, S., Ehleringer, B., Evans, R.D., Lott, M., Martinelli, L.A., Pockman, W.T., Sandquist, D., Sparks, J.P., Sperry, L., Williams, D., and Ehleringer, J.R. (2002) Heavy and light beer: A carbon isotope approach to detect $\mathrm{C}_{4}$ carbon in beers of different origins, styles, and prices. Journal of Agricultural and Food Chemistry, 50 (22), 6413-6418.

39. Fry, B. (2008) Stable Isotope Ecology, Springer, New York.

40. Post, D.M. (2002) Using stable isotopes to estimate trophic position: Models, methods and assumptions. Ecology, 83 (3), 703-718.

41. Fuller, B.T., Fuller, J.L., Sage, N.E., Harris, D.A., O’Connell, T.C., and Hedges, R.E.M. (2004) Nitrogen balance and $\delta^{15} \mathrm{~N}$ : Why you're not what you eat during pregnancy. Rapid Communications in Mass Spectrometry, 18 (23), 2889-2896.

42. Fuller, B.T., Fuller, J.L., Sage, N.E., Harris, D.A., O’Connell, T.C., and Hedges, R.E.M. (2005) Nitrogen balance and $\delta^{15} \mathrm{~N}$ : Why you're not what you eat during nutritional stress. Rapid Communications in Mass Spectrometry, 19 (18), 2497-2506.

43. Petzke, K.J., and Lemke, S. (2009) Hair protein and amino acid ${ }^{13} \mathrm{C}$ and ${ }^{15} \mathrm{~N}$ abundances take more than 4 weeks to clearly prove influences of animal protein intake in young women with a habitual daily protein consumption of more than $1 \mathrm{~g}$ per $\mathrm{kg}$ body weight. Rapid Communications in Mass Spectrometry, 23 (16), 2411-2420.

44. Buchardt, B., Bunch, V., and Helin, P. (2007) Fingernails and diet: Stable isotope signatures of a marine hunting community from modern Uummannaq, North Greenland. Chemical Geology, 244 (1-2), 316-329.

45. Krouse, H.R., and Grinenko, V.A. (eds.) (1991) Stable isotopes: Natural and anthropogenic sulphur in the environment, Published on behalf of the Scientific Committee on Problems of the Environment (SCOPE) of the International Council of Scientific Unions (ICSU) in collaboration with the United Nations Environment Programme by Wiley, Chichester; New York. 
46. Zazzo, A., Monahan, F.J., Moloney, A.P., Green, S., and Schmidt, O. (2011) Sulphur isotopes in animal hair track distance to sea. Rapid Communications in Mass Spectrometry, 25 (17), 2371-2378.

47. Vautour, G., Poirier, A., and Widory, D. (2015) Tracking mobility using human hair: What can we learn from lead and strontium isotopes? Science \& Justice, 55 (1), 63-71.

48. Font, L., van der Peijl, G., van Leuwen, C., van Wetten, I., and Davies, G.R. (2015) Identification of the geographical place of origin of an unidentified individual by multiisotope analysis. Science \& Justice, 55 (1), 34-42.

49. Tipple, B.J., Valenzuela, L.O., and Ehleringer, J.R. (2018) Strontium isotope ratios of human hair record intra-city variations in tap water source. Scientific Reports, 8 (1).

50. Nakano, T. (2016) Potential uses of stable isotope ratios of $\mathrm{Sr}, \mathrm{Nd}$, and $\mathrm{Pb}$ in geological materials for environmental studies. Proceedings of the Japan Academy, Series B, 92 (6), $167-184$.

51. Gulson, B. (2008) Stable lead isotopes in environmental health with emphasis on human investigations. Science of The Total Environment, 400 (1-3), 75-92.

52. Sharpe, A.E., Kamenov, G.D., Gilli, A., Hodell, D.A., Emery, K.F., Brenner, M., and Krigbaum, J. (2016) Lead ( $\mathrm{Pb})$ isotope baselines for studies of ancient human migration and trade in the Maya region. PLOS ONE, 11 (11), e0164871.

53. Hodell, D.A., Quinn, R.L., Brenner, M., and Kamenov, G. (2004) Spatial variation of strontium isotopes $\left({ }^{87} \mathrm{Sr} /{ }^{86} \mathrm{Sr}\right)$ in the Maya region: A tool for tracking ancient human migration. Journal of Archaeological Science, 31 (5), 585-601.

54. Bataille, C.P., Laffoon, J., and Bowen, G.J. (2012) Mapping multiple source effects on the strontium isotopic signatures of ecosystems from the circum-Caribbean region. Ecosphere, 3 (12), art118.

55. Kamenov, G.D., and Gulson, B.L. (2014) The Pb isotopic record of historical to modern human lead exposure. Science of The Total Environment, 490, 861-870.

56. D'Angela, D., and Longinelli, A. (1990) Oxygen isotopes in living mammal's bone phosphate: Further results. Chemical Geology: Isotope Geoscience section, 86 (1), 75-82.

57. Longinelli, A. (1984) Oxygen isotopes in mammal bone phosphate: A new tool for paleohydrological and paleoclimatological research? Geochimica et Cosmochimica Acta, 48 (2), 385-390.

58. Daux, V., Lécuyer, C., Héran, M.-A., Amiot, R., Simon, L., Fourel, F., Martineau, F., Lynnerup, N., Reychler, H., and Escarguel, G. (2008) Oxygen isotope fractionation between human phosphate and water revisited. Journal of Human Evolution, 55 (6), 11381147.

59. Kimmerle, E.H., and Kamenov, G.D. (2015) Linking identity with landscape: Osteological and $\mathrm{Sr}-\mathrm{Pb}$ isotopic methods for biogeoreference, in Biological Affinity in Forensic Identification of Human Skeletal Remains (eds.Berg, G.E., and Ta'ala, S.C.), CRC Press, pp. 239-256.

60. Kamenov, G.D., and Curtis, J.H. (2017) Using carbon, oxygen, strontium, and lead isotopes in modern human teeth for forensic investigations: A critical overview based on data from Bulgaria. Journal of Forensic Sciences, 62 (6), 1452-1459.

61. Kamenov, G.D. (2008) High-precision Pb isotopic measurements of teeth and environmental samples from Sofia (Bulgaria): Insights for regional lead sources and possible pathways to the human body. Environmental Geology, 55 (3), 669-680. 
62. Sharp, Z.D., Atudorei, V., Panarello, H.O., Fernández, J., and Douthitt, C. (2003) Hydrogen isotope systematics of hair: Archeological and forensic applications. Journal of Archaeological Science, 30 (12), 1709-1716.

63. Mancuso, C.J., and Ehleringer, J.R. (2018) Resident and nonresident fingernail isotopes reveal diet and travel patterns. Journal of Forensic Sciences.

64. Mancuso, C.J., and Ehleringer, J.R. (2018) Strontium isotope ratios $\left({ }^{87} \mathrm{Sr} /{ }^{86} \mathrm{Sr}\right)$ of human fingernail clippings reveal multiple location signals. Rapid Communications in Mass Spectrometry.

65. Mancuso, C.J., and Ehleringer, J.R. (2018) Traveling there and back again: A fingernail's tale. Journal of Forensic Sciences.

66. Lee-Thorp, J.A. (2008) On isotopes and old bones. Archaeometry, 50 (6), 925-950.

67. Rauch, E., Rummel, S., Lehn, C., and Büttner, A. (2007) Origin assignment of unidentified corpses by use of stable isotope ratios of light (bio-) and heavy (geo-) elements-A case report. Forensic Science International, 168 (2-3), 215-218.

68. Schwarcz, H.P., and Walker, P.L. (2006) Characterization of a murder victim using stable isotopic analyses (In: Abstracts of AAPA Poster and Podium Presentations). American Journal of Physical Anthropology, 129 (S42), 160.

69. Meier-Augenstein, W. (2018) Stable Isotope Forensics: Methods and Forensic Applications of Stable Isotope Analysis, Second Edition, John Wiley \& Sons, Ltd, Hoboken, NJ.

70. Luz, B., Kolodny, Y., and Horowitz, M. (1984) Fractionation of oxygen isotopes between mammalian bone-phosphate and environmental drinking water. Geochimica et Cosmochimica Acta, 48 (8), 1689-1693.

71. Chenery, C., Müldner, G., Evans, J., Eckardt, H., and Lewis, M. (2010) Strontium and stable isotope evidence for diet and mobility in Roman Gloucester, UK. Journal of Archaeological Science, 37 (1), 150-163.

72. Price, T.D., Knipper, C., Grupe, G., and Smrcka, V. (2004) Strontium isotopes and prehistoric human migration: The Bell Beaker Period in Central Europe. European Journal of Archaeology, 7 (1), 9-40.

73. Lee-Thorp, J., and Sponheimer, M. (2003) Three case studies used to reassess the reliability of fossil bone and enamel isotope signals for paleodietary studies. Journal of Anthropological Archaeology, 22 (3), 208-216.

74. Holden, J.L., Clement, J.G., and Phakey, P.P. (2009) Age and temperature related changes to the ultrastructure and composition of human bone mineral. Journal of Bone and Mineral Research, 10 (9), 1400-1409.

75. Grynpas, M. (1993) Age and disease-related changes in the mineral of bone. Calcified Tissue International, 53 (S1), S57-S64.

76. Simmons, E.D., Pritzker, K.P.H., and Grynpas, M.D. (1991) Age-related changes in the human femoral cortex. Journal of Orthopaedic Research, 9 (2), 155-167.

77. Wopenka, B., and Pasteris, J.D. (2005) A mineralogical perspective on the apatite in bone. Materials Science and Engineering: C, 25 (2), 131-143.

78. Iacumin, P., Bocherens, H., Mariotti, A., and Longinelli, A. (1996) Oxygen isotope analyses of co-existing carbonate and phosphate in biogenic apatite: A way to monitor diagenetic alteration of bone phosphate? Earth and Planetary Science Letters, 142 (1-2), 16. 
79. Passey, B.H., Cerling, T.E., and Levin, N.E. (2007) Temperature dependence of oxygen isotope acid fractionation for modern and fossil tooth enamels. Rapid Communications in Mass Spectrometry, 21 (17), 2853-2859.

80. Kusaka, S., and Nakano, T. (2014) Carbon and oxygen isotope ratios and their temperature dependence in carbonate and tooth enamel using a GasBench II preparation device: Letter to the Editor. Rapid Communications in Mass Spectrometry, 28 (5), 563-567.

81. Chesson, L.A., Berg, G.E., Kenyhercz, M.W., and Regan, L.A. (in review) Addressing data comparability in the creation of combined datasets of bioapatite carbon and oxygen isotopic compositions. Archaeometry.

82. Kim, S.-T., Coplen, T.B., and Horita, J. (2015) Normalization of stable isotope data for carbonate minerals: Implementation of IUPAC guidelines. Geochimica et Cosmochimica Acta, 158, 276-289.

83. Stryer, L. (1975) Biochemistry, W.H.Freeman \& Co Ltd.

84. Ambrose, S.H., and Norr, L. (1993) Experimental evidence for the relationship of the carbon isotope ratios of whole diet and dietary protein to those of bone collagen and carbonate, in Prehistoric Human Bone (eds.Lambert, J.B., and Grupe, G.), Springer Berlin Heidelberg, Berlin, Heidelberg, pp. 1-37.

85. Tieszen, L.L., and Fagre, T. (1993) Effect of diet quality and composition on the isotopic composition of respiratory $\mathrm{CO}_{2}$, bone collagen, bioapatite, and soft tissues, in Prehistoric Human Bone (eds.Lambert, J.B., and Grupe, G.), Springer Berlin Heidelberg, Berlin, Heidelberg, pp. 121-155.

86. Schwarcz, H.P., and Schoeninger, M.J. (1991) Stable isotope analyses in human nutritional ecology. American Journal of Physical Anthropology, 34 (S13), 283-321.

87. Schoeninger, M., DeNiro, M., and Tauber, H. (1983) Stable nitrogen isotope ratios of bone collagen reflect marine and terrestrial components of prehistoric human diet. Science, 220 (4604), 1381-1383.

88. Regan, L.A. (2006) Isotopic determination of region of origin in modern peoples: Applications for identification of U.S. war-dead from the Vietnam Conflict.

89. Bartelink, E.J., Berg, G.E., Beasley, M.M., and Chesson, L.A. (2014) Application of stable isotope forensics for predicting region of origin of human remains from past wars and conflicts. Annals of Anthropological Practice, 38 (1), 124-136.

90. Bartelink, E.J., Chesson, L.A., Tipple, B.J., and Berg, G.E. (2015) Recent applications of stable isotope forensics for tracking region-of-origin and residence patterns of unidentified individuals. Proceedings of the American Academy of Forensic Sciences, 21, 357-358.

91. Bartelink, E.J., Berg, G.E., Chesson, L.A., Tipple, B.J., Beasley, M.M., Prince-Buitenhuys, J.R., MacInnes, H., MacKinnon, A.T., and Latham, K.E. (2018) Applications of stable isotope forensics for geolocating unidentified human remains from past conflict situations and large-scale humanitarian efforts, in New Perspectives in Forensic Human Skeletal Identification (eds.Latham, K.E., Bartelink, E.J., and Finnegan, M.), Elsevier, pp. 175-184.

92. Holland, T.D., Berg, G.E., and Regan, L.A. (2012) Identification of a United States airman using stable isotopes. Proceedings of the American Academy of Forensic Sciences, 18, 420421.

93. Berg, G.E., and Kenyhercz, M.W. (2017) Isolocate.

94. Pestle, W.J., Crowley, B.E., and Weirauch, M.T. (2014) Quantifying inter-laboratory variability in stable isotope analysis of ancient skeletal remains. PLoS ONE, 9 (7), e102844. 
95. Bell, L.S., Lee-Thorp, J.A., and Elkerton, A. (2010) Sailing against the wind: Reply to Millard and Schroeder: 'True British sailors': A comment on the origin of the men of the Mary Rose. Journal of Archaeological Science, 37 (4), 683-686.

96. Teitelbaum, S.L. (2000) Bone resorption by osteoclasts. Science, 289 (5484), 1504-1508.

97. Martin, R.B., Burr, D.B., Sharkey, N.A., and Fyhrie, D.P. (2015) Skeletal Tissue Mechanics, Springer New York, New York, NY.

98. Hedges, R.E.M., Clement, J.G., Thomas, C.D.L., and O'Connell, T.C. (2007) Collagen turnover in the adult femoral mid-shaft: Modeled from anthropogenic radiocarbon tracer measurements. American Journal of Physical Anthropology, 133 (2), 808-816.

99. Pearson, O.M., and Lieberman, D.E. (2004) The aging of Wolff' s "law": Ontogeny and responses to mechanical loading in cortical bone. American Journal of Physical Anthropology, 125 (S39), 63-99.

100. Hillson, S. (1996) Dental Anthropology, Cambridge University Press, Cambridge.

101. Scheuer, L., and Black, S.M. (2004) The Juvenile Skeleton, Elsevier Academic Press, London; San Diego, Calif.

102. Richards, M.P., Mays, S., and Fuller, B.T. (2002) Stable carbon and nitrogen isotope values of bone and teeth reflect weaning age at the Medieval Wharram Percy site, Yorkshire, UK. American Journal of Physical Anthropology, 119 (3), 205-210.

103. Fuller, B.T., Richards, M., and Mays, S. (2001) Stable isotopes from bone and tooth collagen reveal dietary patterns and the age of weaning at the medieval village site of Wharram Percy. Journal of Bone and Mineral Research, 16 (6), 1190.

104. Jay, M., Fuller, B.T., Richards, M.P., Knüsel, C.J., and King, S.S. (2008) Iron Age breastfeeding practices in Britain: Isotopic evidence from Wetwang Slack, East Yorkshire. American Journal of Physical Anthropology, 136 (3), 327-337.

105. Wright, L.E., and Schwarcz, H.P. (1998) Stable carbon and oxygen isotopes in human tooth enamel: Identifying breastfeeding and weaning in prehistory. American Journal of Physical Anthropology, 106 (1), 1-18.

106. Deniro, M.J., Schoeninger, M.J., and Hastorf, C.A. (1985) Effect of heating on the stable carbon and nitrogen isotope ratios of bone collagen. Journal of Archaeological Science, 12 (1), 1-7.

107. Snoeck, C., Schulting, R.J., Lee-Thorp, J.A., Lebon, M., and Zazzo, A. (2016) Impact of heating conditions on the carbon and oxygen isotope composition of calcined bone. Journal of Archaeological Science, 65, 32-43.

108. Munro, L.E., Longstaffe, F.J., and White, C.D. (2008) Effects of heating on the carbon and oxygen-isotope compositions of structural carbonate in bioapatite from modern deer bone. Palaeogeography, Palaeoclimatology, Palaeoecology, 266 (3-4), 142-150.

109. Hüls, C.M., Erlenkeuser, H., Nadeau, M.-J., Grootes, P.M., and Andersen, N. (2010) Experimental study on the origin of cremated bone apatite carbon. Radiocarbon, 52 (02), 587-599.

110. Harvig, L., Frei, K.M., Price, T.D., and Lynnerup, N. (2014) Strontium isotope signals in cremated petrous portions as indicator for childhood origin. PLoS ONE, 9 (7), e101603.

111. Bowen, G.J., Chesson, L., Nielson, K., Cerling, T.E., and Ehleringer, J.R. (2005) Treatment methods for the determination of $\delta^{2} \mathrm{H}$ and $\delta^{18} \mathrm{O}$ of hair keratin by continuous-flow isotoperatio mass spectrometry. Rapid Communications in Mass Spectrometry, 19 (17), 23712378. 
112. Fraser, I., Meier-Augenstein, W., and Kalin, R.M. (2008) Stable isotope analysis of human hair and nail samples: The effects of storage on samples. Journal of Forensic Sciences, $\mathbf{5 3}$ (1), 95-99.

113. Chesson, L.A., Podlesak, D.W., Erkkila, B.R., Cerling, T.E., and Ehleringer, J.R. (2010) Isotopic consequences of consumer food choice: Hydrogen and oxygen stable isotope ratios in foods from fast food restaurants versus supermarkets. Food Chemistry, 119 (3), 12501256.

114. Nardoto, G.B., Silva, S., Kendall, C., Ehleringer, J.R., Chesson, L.A., Ferraz, E.S.B., Moreira, M.Z., Ometto, J.P.H.B., and Martinelli, L.A. (2006) Geographical patterns of human diet derived from stable-isotope analysis of fingernails. American Journal of Physical Anthropology, 131 (1), 137-146.

115. Santamaria-Fernandez, R., Giner Martínez-Sierra, J., Marchante-Gayón, J.M., GarcíaAlonso, J.I., and Hearn, R. (2009) Measurement of longitudinal sulfur isotopic variations by laser ablation MC-ICP-MS in single human hair strands. Analytical and Bioanalytical Chemistry, 394 (1), 225-233.

116. Meier-Augenstein, W. (2006) Stable isotope fingerprinting - Chemical element "DNA"?, in Forensic Human Identification (eds.Black, S., and Thompson, T.), CRC Press, pp. 29-53.

117. Wilson, A.S. (2005) Hair as a bioresource in archaeological study, in Hair in Toxicology (eds.Tobin, D.J.), Royal Society of Chemistry, Cambridge, pp. 321-347.

118. Huelsemann, F., Flenker, U., Koehler, K., and Schaenzer, W. (2009) Effect of a controlled dietary change on carbon and nitrogen stable isotope ratios of human hair. Rapid Communications in Mass Spectrometry, 23 (16), 2448-2454.

119. Petzke, K.J., Boeing, H., and Metges, C.C. (2005) Choice of dietary protein of vegetarians and omnivores is reflected in their hair protein ${ }^{13} \mathrm{C}$ and ${ }^{15} \mathrm{~N}$ abundance. Rapid Communications in Mass Spectrometry, 19 (11), 1392-1400.

120. Wilson, A.S., and Gilbert, M.T.P. (2007) Hair and nail, in Forensic Human Identification (eds.Thompson, T., and Black, S.), CRC Press, pp. 147-174.

121. Remien, C.H., Adler, F.R., Chesson, L.A., Valenzuela, L.O., Ehleringer, J.R., and Cerling, T.E. (2014) Deconvolution of isotope signals from bundles of multiple hairs. Oecologia, 175 (3), 781-789.

122. O’Brien, D.M., and Wooller, M.J. (2007) Tracking human travel using stable oxygen and hydrogen isotope analyses of hair and urine. Rapid Communications in Mass Spectrometry, 21 (15), 2422-2430.

123. Landwehr, J.M., Meier-Augenstein, W., and Kemp, H.F. (2011) A counter-intuitive approach to calculating non-exchangeable ${ }^{2} \mathrm{H}$ isotopic composition of hair: Treating the molar exchange fraction $\mathrm{f}_{\mathrm{E}}$ as a process-related rather than compound-specific variable. Rapid Communications in Mass Spectrometry, 25 (2), 301-306.

124. Meier-Augenstein, W., Chartrand, M.M.G., Kemp, H.F., and St-Jean, G. (2011) An interlaboratory comparative study into sample preparation for both reproducible and repeatable forensic ${ }^{2} \mathrm{H}$ isotope analysis of human hair by continuous flow isotope ratio mass spectrometry. Rapid Communications in Mass Spectrometry, 25 (21), 3331-3338.

125. Meier-Augenstein, W., and Kemp, H.F. (2012) Stable Isotope Analysis: Hair and Nails, in Wiley Encyclopedia of Forensic Science (eds.Jamieson, A., and Moenssens, A.), John Wiley \& Sons, Ltd, Chichester, UK.

126. Coplen, T.B., and Qi, H. (2012) USGS42 and USGS43: Human-hair stable hydrogen and oxygen isotopic reference materials and analytical methods for forensic science and 
implications for published measurement results. Forensic Science International, 214 (1-3), 135-141.

127. Coplen, T.B., and Qi, H. (2016) A revision in hydrogen isotopic composition of USGS42 and USGS43 human-hair stable isotopic reference materials for forensic science. Forensic Science International, 266, 222-225.

128. Meier-Augenstein, W., Hobson, K.A., and Wassenaar, L.I. (2013) Critique: Measuring hydrogen stable isotope abundance of proteins to infer origins of wildlife, food and people. Bioanalysis, 5 (7), 751-767.

129. Coleman, M., and Meier-Augenstein, W. (2014) Ignoring IUPAC guidelines for measurement and reporting of stable isotope abundance values affects us all: Letter to the Editor. Rapid Communications in Mass Spectrometry, 28 (17), 1953-1955.

130. Dunn, P., and Carter, J. (2018) Good Practice Guide for Isotope Ratio Mass Spectrometry. 131. Meier-Augenstein, W., and Schimmelmann, A. (2018) A guide for proper utilisation of stable isotope reference materials. Isotopes in Environmental and Health Studies, 1-16.

132. Bataille, C.P., von Holstein, I.C.C., Laffoon, J.E., Willmes, M., Liu, X.-M., and Davies, G.R. (2018) A bioavailable strontium isoscape for Western Europe: A machine learning approach. PLOS ONE, 13 (5), e0197386.

133. Willmes, M., Bataille, C.P., James, H.F., Moffat, I., McMorrow, L., Kinsley, L., Armstrong, R.A., Eggins, S., and Grün, R. (2018) Mapping of bioavailable strontium isotope ratios in France for archaeological provenance studies. Applied Geochemistry, 90, 75-86.

134. Hülsemann, F., Lehn, C., Schneider, S., Jackson, G., Hill, S., Rossmann, A., Scheid, N., Dunn, P.J.H., Flenker, U., and Schänzer, W. (2015) Global spatial distributions of nitrogen and carbon stable isotope ratios of modern human hair. Rapid Communications in Mass Spectrometry, 29 (22), 2111-2121.

135. Font, L., van der Peijl, G., van Wetten, I., Vroon, P., van der Wagt, B., and Davies, G. (2012) Strontium and lead isotope ratios in human hair: Investigating a potential tool for determining recent human geographical movements. Journal of Analytical Atomic Spectrometry, 27 (5), 719.

136. Chau, T.H., Tipple, B.J., Hu, L., Fernandez, D.P., Cerling, T.E., Ehleringer, J.R., and Chesson, L.A. (2017) Reconstruction of travel history using coupled $\delta^{18} \mathrm{O}$ and ${ }^{87} \mathrm{Sr} /{ }^{86} \mathrm{Sr}$ measurements of hair. Rapid Communications in Mass Spectrometry, 31 (6), 583-589.

137. Varrica, D., Dongarrà, G., Alaimo, M.G., Monna, F., Losno, R., Sanna, E., De Giudici, G., and Tamburo, E. (2018) Lead isotopic fingerprint in human scalp hair: The case study of Iglesias mining district (Sardinia, Italy). Science of The Total Environment, 613-614, 456461.

138. Bentley, R.A. (2006) Strontium isotopes from the Earth to the archaeological skeleton: A review. Journal of Archaeological Method and Theory, 13 (3), 135-187.

139. Gulson, B.L., Jameson, C.W., and Gillings, B.R. (1997) Stable lead isotopes in teeth as indicators of past domicile-A potential new tool in forensic science? Journal of Forensic Sciences, 42 (5), 787-791.

140. Evans, J.A., and Tatham, S. (2004) Defining 'local signature' in terms of Sr isotope composition using a tenth- to twelfth-century Anglo-Saxon population living on a Jurassic clay-carbonate terrain, Rutland, UK. Geological Society, London, Special Publications, 232 (1), 237-248. 
141. Kamenov, G.D., Kimmerle, E.H., Curtis, J.H., and Norris, D. (2014) Georeferencing a cold case victim with lead, strontium, carbon, and oxygen isotopes. Annals of Anthropological Practice, 38 (1), 137-154. 